\title{
Characterizing Reaction of Soybean to Phialophora gregata Using Pathogen Population Density and DNA Quantity in Stems
}

\author{
A. E. Impullitti, Graduate Research Assistant, and D. K. Malvick, Assistant Professor, Department of Plant Pathol- \\ ogy, University of Minnesota, St. Paul 55108; and C. R. Grau, Professor, Department of Plant Pathology, University \\ of Wisconsin-Madison, 1630 Linden Drive, Madison 53706
}

\begin{abstract}
Impullitti, A. E., Malvick, D. K., and Grau, C. R. 2009. Characterizing reaction of soybean to Phialophora gregata using pathogen population density and DNA quantity in stems. Plant Dis. 93:734-740.

Evaluation of soybean germplasm for resistance to brown stem rot (BSR) is typically based on symptom severity. However, this approach may not reflect the level of colonization of soybean by the casual agent, Phialophora gregata. A potentially more accurate method to characterize resistance to BSR is to estimate pathogen quantity. The primary goal of this study was to evaluate soybean accessions for resistance to BSR based on the quantity of pathogen in stems. Plants were collected from experiments in field and controlled environments, and CFU and pathogen DNA quantity were determined using dilution plating techniques and real-time quantitative PCR (qPCR), respectively. In the field, the BSR-susceptible cultivars Corsoy 79 and Century 84 expressed greater than $73 \%$ foliar and stem symptom severity and had the highest pathogen population density, with a range from $\log _{10} 4.3$ to $4.7 \mathrm{CFU}$ per gram of stem tissue. The resistant cultivar Bell expressed less than $10 \%$ foliar symptom severity, but had a pathogen population density that was not statistically different from the susceptible accessions. CFU measured in Dwight and L84-5873 were consistently lower than CFU in susceptible accessions and several resistant accessions. The amount of pathogen DNA differed among accessions in controlled environments. For example, Corsoy 79 and Century 84 had the highest pathogen DNA quantity, ranging from $\log _{10} 6.19$ to 6.65 copies, whereas the resistant cultivars Bell, Dwight, and L845873 had significantly lower DNA quantities, ranging from $\log _{10} 2.04$ to 2.91 copies. PI 437833 and IA2008R expressed low symptom severity but contained high DNA quantities. Pella 86, a highly symptomatic cultivar, had fewer CFU and lower DNA quantity in comparison to two other highly symptomatic cultivars and some cultivars with low symptom severity. These results suggest that some accessions express resistance to both pathogen colonization and symptom development, while others are resistant to symptom development but not to pathogen colonization. Results also indicate that resistant and susceptible accessions can be distinguished based on DNA quantity in controlled environments. In the field, differences between the pathogen population in resistant and susceptible cultivars were less distinct, possibly due to when plants were assayed.
\end{abstract}

Brown stem rot (BSR) is a common and widespread disease of soybean (Glycine $\max (\mathrm{L}$.$) Merr.) in the north-central region$ of the United States. Research on the etiology and management of BSR is extensive, but it remains a significant yield-limiting disease of soybean (28). The impact and associated yield loss caused by BSR has been difficult to estimate in a field because the causal agent does not always cause foliar symptoms.

Phialophora gregata W. Gams (Allington \& Chamberlain) (Cadophora gregata Harrington \& McNew (6)) is the casual agent of BSR (1). This fungal pathogen separates into two distinct types, genotype

Corresponding author: Ann E. Impullitti

E-mail: IMPUL001@UMN.EDU

Accepted for publication 29 March 2009.

doi:10.1094/PDIS-93-7-0734

(C) 2009 The American Phytopathological Society
$\mathrm{A}$ and $\mathrm{B}$, based on variation in symptoms produced on soybean and molecular markers in the IGS region $(4,9)$. Genotype A causes interveinal chlorosis of leaves and vascular browning, while genotype B causes vascular browning and little or no foliar symptoms $(4,9)$. The interaction phenotype of a soybean accession is affected by the source of genetic resistance to $P$. gregata and the genotype of the pathogen that is present $(3,9,22)$.

Soybean accessions are evaluated for resistance to BSR based on symptom severity on leaves or in stems, or by qualitative detection of $P$. gregata throughout the length of the stem by isolation $(10,15$, $25,26)$. These assessments may not reflect the level of infection and colonization of soybean by $P$. gregata. A potentially more meaningful approach to characterize resistance is to determine the quantity of $P$. gregata in soybean stems.

Enumeration of pathogen propagules has been employed to characterize resistance to several pathogens such as Macro- phomina phaseolina (Tassi) Goid and the soybean cyst nematode (SCN) Heterodera glycines Ichinohe $(2,17,21,24)$. Quantification of pathogen DNA in host tissue with real-time quantitative PCR (qPCR) has potential as a fast and efficient method to evaluate resistance. This approach has been used with alfalfa and pepper, where the DNA content of Verticillium alboatrum and Phytophthora capsici, respectively, was lower in resistant than in susceptible cultivars $(11,23)$. A sensitive and rapid qPCR assay for $P$. gregata is available to detect and quantify $P$. gregata in soybean stems and is potentially a novel approach to characterize resistance to this pathogen (13).

The goal of this study was to compare different methods to evaluate soybean accessions for their resistance to BSR. The objectives were to: (i) characterize resistance to $P$. gregata in the field based on CFU and quantity of pathogen DNA in stem tissue; (ii) characterize sources of resistance in controlled environments for their reaction to genotypes $\mathrm{A}$ and $\mathrm{B}$ based on pathogen DNA quantity; and (iii) evaluate the relationship between the pathogen DNA quantity, CFU, and symptom severity.

\section{MATERIALS AND METHODS}

Field experiments. Experiments were conducted in a field with a history of BSR at the West Madison Agriculture Research Station from 2002 to 2004. The field has Plano silt loam soil ( $\mathrm{pH} \mathrm{6.5),} \mathrm{was} \mathrm{planted}$ continuously to soybeans for the preceding 5 years, and is naturally infested with genotypes A and B of $P$. gregata. Soybean accessions planted in 2002 were selected based on their reported susceptibility or resistance to BSR (Table 1) (27). In 2002 , single-row plots $6.1 \mathrm{~m}$ long and spaced $0.75 \mathrm{~m}$ apart were planted at a rate of eight seeds per $0.3 \mathrm{~m}$ of row. Each accession was replicated three times in a randomized complete block design. In 2003 and 2004, a subset of 12 and 8 accessions, respectively, was selected from those planted in 2002 (Table 1). The subsets consisted of susceptible accessions and potentially resistant accessions to genotypes A and B of $P$. gregata based on pathogen colonization and symptoms.

Experiments in controlled environments. The same accessions evaluated in the field in 2003 and 2004 were evaluated in greenhouse and growth chamber envi- 
ronments (Table 1). Three independent experiments were conducted for 10 weeks from October 2002 to June 2003. Seeds were sown in 96-well flats filled with medium-grade vermiculite and infested with Bradyrhizobium japonicum (Nitrogen Inoculants, Lipatech, Inc., Milwaukee, WI). Inoculum was produced by growing genotype $\mathrm{A}$, isolate $\mathrm{F} 5-3$, and genotype $\mathrm{B}$, isolate F3-8, in green bean broth (GBB) (9). Mycelial fragments and spores of each isolate were blended using a Braun Multiquick Handblender (Braun, Boston, MA), counted using a hemacytometer, and inoculum adjusted to $4.0 \times 10^{7}$ spores $\mathrm{ml}^{-1}$. Plants were grown to the VC-V1 growth stage, and rootdip inoculated with genotypes $\mathrm{A}, \mathrm{B}$, or a combination of A and B (1:1) $(9,19,20)$. Sterile GBB was used as a control.

Nine plants were inoculated per treatment and distributed into three replications in $15.2-\mathrm{cm}$ pots containing a mixture of steam pasteurized field soil, sand, and Metro Mix (Scotts, Marysville, OH) (1:1:2). The pots were arranged in a randomized complete block design, plants were watered daily, and nutrients were supplemented weekly using Technigro fertilizer (20-9-20) (Sun Gro, Bellevue, WA). Plants in the greenhouse were grown at 22 to $26^{\circ} \mathrm{C}$ with a 14 -h photoperiod for 10 weeks. Plants in the growth chamber were grown at $26^{\circ} \mathrm{C}$ with a 12 -h photoperiod until growth stage R1 (approximately 3 weeks) or until unifoliate leaves expressed symptoms, and then the temperature was lowered to $22^{\circ} \mathrm{C}$ for 7 weeks.

Symptom assessment. Foliar and stem symptom severities of BSR were evaluated using the Horsfall-Barratt scale (8). Foliar symptoms in the field were rated every 4 days from growth stage R5 to R7 (19). Internal browning was assessed in five stems per plot, which were randomly selected at R7 and split longitudinally. In the greenhouse and growth chamber, foliar symptoms were rated every 3 days for 4 weeks, beginning with the onset of symptoms. Internal symptom severity was rated at R5, which was approximately 8 weeks after inoculation.

Pathogen population assessment. Five stems of each accession were cut at the soil line and collected from each replication at the R7 growth stage. Stems were trimmed to $18 \mathrm{~cm}$ in length and air-dried for $48 \mathrm{~h}$ at $25^{\circ} \mathrm{C}$. The five stems were combined and ground in a Cyclone Sample Mill (UDY Corp, Fort Collins, CO) that was cleaned with forced air between samples. Ground tissue was stored at $4^{\circ} \mathrm{C}$ until the population density of $P$. gregata was estimated by dilution plating on $P$. gregata medium (PGM) (14). Petri plates were placed at $12^{\circ} \mathrm{C}$ in darkness for 28 days, and colonies with the colony phenotype of $P$. gregata were counted and data adjusted to log CFU per gram of stem tissue.

DNA was extracted from five subsamples of ground stem tissue from each field plot in 2002, 20 subsamples in 2003, and one in 2004. For the greenhouse and growth chamber, the lower $10 \mathrm{~cm}$ of the three plants in each pot were ground and pooled. DNA was extracted using a modified protocol to decrease potential PCR inhibitors (12). Standard PCR (sPCR) with DNA samples was performed using primers to identify genotypes $\mathrm{A}$ and $\mathrm{B}$ of $P$. gregata, and qPCR was performed using primers and a TaqMan probe specific for $P$. gregata using an ABI 7000 detection system (Applied Biosystems, Foster City, CA) (13). Sterile molecular grade water was used instead of DNA for negative controls, and DNA from genotypes $\mathrm{A}$ and $\mathrm{B}$ was used as positive controls. For qPCR, absolute estimation of copy numbers was based on standard curves using dilutions of a cloned DNA fragment (13). The correlation coefficient of cloned standards to copy number for $\mathrm{qPCR}$ reactions ranged from 0.95 to 0.99 , and the reaction slopes ranged from -2.75 to -3.33 .

Data analysis. Prior to data analysis, all Horsfall-Barratt disease severity ratings were converted to percentages. The mean percentage for all five stems per plot was calculated, and CFU g ${ }^{-1}$ stem tissue and DNA copy number were $\log _{10}$ transformed. An area under the disease progress curve (AUDPC) was calculated using foliar symptom ratings. Foliar and stem severity ratings from the 2002 and 2003 field experiments was combined and analyzed together because there was no year interaction. Data for the pathogen population density and DNA quantity in stems in

Table 1. Evaluation of soybean accessions to Phialophora gregata in a naturally infested field in 2002 based on disease severity and CFU of the pathogen

\begin{tabular}{|c|c|c|c|c|c|}
\hline \multirow[b]{2}{*}{ Accessions $^{b}$} & \multicolumn{2}{|c|}{$\begin{array}{c}\text { Brown stem rot } \\
\text { symptom severity }\end{array}$} & \multirow[b]{2}{*}{ AUDPC $^{c}$} & \multirow[b]{2}{*}{$\mathrm{CFU} / \mathrm{g}^{\mathrm{d}}$} & \multirow[b]{2}{*}{ Years eval. in field } \\
\hline & Foliar (\%) & Stem (\%) & & & \\
\hline \multicolumn{6}{|l|}{ Resistant } \\
\hline Bell (I) & 5 & 9 & 20 & 5.26 & 2003, 2004 \\
\hline BSR101 (I) & 15 & 9 & 85 & 4.79 & 2003,2004 \\
\hline Chamberlain (III) & 20 & 24 & 57 & 4.32 & $\mathrm{na}^{\mathrm{e}}$ \\
\hline Dwight (II) & 12 & 15 & 72 & 3.73 & 2003,2004 \\
\hline IA2008R (II) & 5 & 5 & 34 & 4.03 & 2003, 2004 \\
\hline Jack (II) & 31 & 20 & 112 & 4.41 & na \\
\hline Savoy (II) & 24 & 8 & 119 & 5.13 & 2003 \\
\hline LN 80-7579 (II) & 19 & 11 & 103 & 5.20 & 2003 \\
\hline LN 84-5873 (II) & 17 & 13 & 77 & 2.55 & 2003 \\
\hline LN 94-14862 (II) & 11 & 28 & 188 & 5.28 & 2003 \\
\hline PI 88788 (III) & 52 & 43 & 286 & 4.32 & na \\
\hline PI 209332 (IV) & 11 & 14 & 125 & 4.26 & na \\
\hline PI $437833(R b s 2)(\mathrm{I})$ & 8 & 18 & 40 & 4.82 & 2003,2004 \\
\hline PI 567323A (I) & 40 & 33 & 244 & 4.84 & na \\
\hline PI 567479 (IV) & 25 & 32 & 237 & 4.00 & na \\
\hline \multicolumn{6}{|l|}{ Susceptible } \\
\hline Century 84 (II) & 82 & 64 & 588 & 5.39 & 2003, 2004 \\
\hline Corsoy 79 (II) & 83 & 61 & 642 & 5.03 & 2003,2004 \\
\hline Pella 86 (III) & 82 & 82 & 762 & 2.75 & 2003, 2004 \\
\hline Williams 82 (III) & 49 & 66 & 570 & 3.48 & na \\
\hline \multicolumn{6}{|l|}{ Other accessions } \\
\hline Fayette (III) & 40 & 24 & 147 & 4.85 & na \\
\hline Hartwig (V) & 12 & 22 & 71 & 3.80 & na \\
\hline Mandarin (Ottawa) (0) & 0 & 5 & 5 & 5.18 & na \\
\hline Newton (II) & 69 & 64 & 500 & 5.24 & na \\
\hline LN 86-1947 (I) & 1 & 11 & 2 & 5.17 & na \\
\hline LN 89-5612 (III) & 41 & 57 & 345 & 3.92 & na \\
\hline LN 89-5717 (IV) & 5 & 2 & 45 & 2.68 & na \\
\hline LN 94-10480 (II) & 11 & 41 & 82 & 3.82 & na \\
\hline LN 94-10504 (II) & 8 & 11 & 117 & 4.49 & na \\
\hline LN 94-14862-97-2 (II) & 4 & 18 & 61 & 4.03 & na \\
\hline LN 94-15292-97 (II) & 40 & 36 & 197 & 4.72 & na \\
\hline LN 95-14887 (II) & 36 & 18 & 142 & 4.54 & na \\
\hline PI 297543 (II) & 40 & 42 & 347 & 4.30 & na \\
\hline PI 391589 (I) & 2 & 7 & 9 & 4.55 & na \\
\hline PI 437934A (I) & 5 & 11 & 18 & 4.34 & na \\
\hline PI 438496A (II) & 88 & 61 & 593 & 3.45 & na \\
\hline PI 438497B (III) & 85 & 77 & 1,030 & 4.60 & na \\
\hline PI 561353 (I) & 1 & 32 & 8 & 4.61 & na \\
\hline PI 567157A (I) & 1 & 41 & 2 & 4.59 & na \\
\hline$P$ value & 0.001 & 0.001 & 0.001 & 0.001 & \\
\hline $\operatorname{LSD}(P=0.05)$ & 34 & 26 & 283 & 1.29 & \\
\hline
\end{tabular}

${ }^{a}$ Severity ratings at growth stage $\mathrm{R} 7$.

${ }^{\mathrm{b}}$ Maturity group of soybean accessions indicated in parentheses.

${ }^{c}$ Area under the disease progress curve.

${ }^{\mathrm{d}} \log _{10} \mathrm{CFU}$ of $P$. gregata per gram of soybean stem tissue.

e Accessions not evaluated. 
2002, 2003, and 2004 were analyzed separately. Accessions evaluated in consecutive years were used for correlation analysis. Growth chamber and greenhouse data for three replicate experiments were combined because there were no significant differences between experiments after preliminary analyses. ANOVA, Fisher's LSD $(P<$ $0.05)$, linear correlation $\left(r^{2}\right)$, and Spearman rank correlations $\left(R_{s}\right)$ were calculated us- ing SAS software (SAS Institute, Cary, NC).

\section{RESULTS}

Evaluation of soybean accessions in the field. Foliar and stem symptoms of BSR were observed during field experiments. The susceptible cultivar Corsoy 79 and the resistant cultivars BSR101 and Bell, as wells as most other accessions, expressed symptoms characteristic of their reaction to $P$. gregata (Table 1). In further field studies, resistant and susceptible accessions differed in symptom severity, but not significantly in the population density of $P$. gregata in stem tissue (Table 2). The susceptible cultivars Corsoy 79 and Century 84 expressed greater than $73 \%$ foliar and stem symptom severity and had the highest population density in stem tissue in

Table 2. Severity of foliar and stem symptoms and quantity of Phialophora gregata in soybean accessions grown from 2002 to 2004 in a field naturally infested with genotypes A and B

\begin{tabular}{|c|c|c|c|c|c|c|c|c|}
\hline \multirow[b]{3}{*}{ Accessions } & & & \multicolumn{6}{|c|}{ P. gregata population $\left(\log _{10}\right)$} \\
\hline & \multicolumn{2}{|c|}{ Symptoms $(\%)^{\mathrm{a}}$} & \multicolumn{2}{|c|}{2002} & \multicolumn{2}{|c|}{2003} & \multicolumn{2}{|c|}{2004} \\
\hline & Foliar & Stem $^{b}$ & $\mathrm{CFU} / \mathrm{g}^{\mathrm{c}}$ & DNA qty & $\mathrm{CFU} / \mathrm{g}^{\mathrm{c}}$ & DNA qty ${ }^{d}$ & $\mathrm{CFU} / \mathrm{g}^{\mathrm{c}}$ & DNA qty ${ }^{d}$ \\
\hline \multicolumn{9}{|l|}{ Resistant } \\
\hline Bell & 9 & 14 & 4.26 & 5.90 & 3.96 & 6.08 & 2.97 & 4.91 \\
\hline BSR101 & 12 & 59 & 4.31 & 6.47 & 3.98 & 5.91 & 1.79 & 4.65 \\
\hline Dwight & 7 & 9 & 2.99 & 6.32 & 2.67 & 5.20 & 2.28 & 3.54 \\
\hline IA2008R & 5 & 7 & 3.22 & 6.87 & 3.39 & 6.29 & 2.92 & 4.61 \\
\hline Savoy & 12 & 23 & 4.45 & 6.18 & 3.51 & 5.94 & $\mathrm{na}^{\mathrm{e}}$ & na \\
\hline LN 80-7579 & 18 & 9 & 4.70 & 6.59 & 3.20 & 5.23 & na & na \\
\hline L 84-5873 & 9 & 12 & 2.89 & 6.14 & 3.52 & 6.09 & 1.00 & 3.85 \\
\hline LN 94-14862 & 6 & 39 & 4.53 & 6.96 & 4.18 & 6.01 & na & na \\
\hline PI 437833(Rbs2) & 5 & 44 & 4.30 & 6.34 & 4.45 & 6.61 & na & na \\
\hline \multicolumn{9}{|l|}{ Susceptible } \\
\hline Corsoy 79 & 93 & 81 & 4.56 & 6.50 & 4.60 & 6.65 & 3.71 & 5.49 \\
\hline Century 84 & 92 & 73 & 4.71 & 6.97 & 4.27 & 6.65 & 2.97 & 5.00 \\
\hline Pella 86 & 85 & 91 & 3.10 & 7.05 & 3.71 & 5.75 & 1.85 & 4.48 \\
\hline$P$ value & $<0.01$ & $<0.01$ & $<0.01$ & $<0.01$ & 0.07 & $<0.01$ & $<0.01$ & $<0.01$ \\
\hline $\mathrm{LSD}^{\mathrm{f}}$ & 10 & 16 & 0.97 & 0.61 & 1.05 & 0.74 & 0.97 & 0.74 \\
\hline
\end{tabular}

${ }^{a}$ Foliar and stem symptom severity data were combined in 2002 and 2003. 2004 not shown.

${ }^{\mathrm{b}}$ Stem ratings are the mean of five stems taken at the R7 growth stage.

${ }^{c} \log _{10} \mathrm{CFU}$ per gram of stem tissue.

${ }^{\mathrm{d}} \log _{10}$ of the quantity of DNA of Phialophora gregata detected in quantitative PCR assays.

e Samples not assayed.

${ }^{\mathrm{f}}$ LSD Fisher's least significant difference.

Table 3. Evaluation of symptom severity and pathogen DNA quantity in soybean accessions inoculated with genotype A or B of Phialophora gregata

\begin{tabular}{|c|c|c|c|c|c|c|}
\hline \multirow[b]{2}{*}{ Accessions } & \multicolumn{3}{|c|}{ Genotype A } & \multicolumn{3}{|c|}{ Genotype B } \\
\hline & Foliar $(\%)^{\mathrm{a}}$ & Stem $(\%)^{\mathbf{b}}$ & DNA qty $\left(\log _{10}\right)^{c}$ & Foliar $(\%)^{\mathrm{a}}$ & Stem $(\%)^{b}$ & DNA qty $\left(\log _{10}\right)^{c}$ \\
\hline \multicolumn{7}{|l|}{ Resistant } \\
\hline Bell & 2 & 2 & 2.33 & 8 & 4 & 2.30 \\
\hline BSR101 & 11 & 4 & 2.24 & 0 & 2 & 1.07 \\
\hline Dwight & 2 & 3 & 2.04 & 6 & 3 & 2.91 \\
\hline IA2008R & 2 & 1 & 4.59 & 1 & 2 & 3.00 \\
\hline Savoy & 2 & 1 & 2.45 & 2 & 2 & 1.69 \\
\hline LN 80-7579 & 24 & 22 & 3.74 & 6 & 4 & 2.71 \\
\hline L 84-5873 & 2 & 1 & 1.51 & 0 & 4 & 1.50 \\
\hline LN 94-14862 & 18 & 3 & 2.44 & 10 & 3 & 2.38 \\
\hline PI 437833 & 22 & 8 & 4.91 & 8 & 4 & 5.33 \\
\hline \multicolumn{7}{|l|}{ Susceptible } \\
\hline Century 84 & 97 & 43 & 6.65 & 6 & 13 & 6.19 \\
\hline Corsoy 79 & 76 & 52 & 6.51 & 7 & 23 & 6.50 \\
\hline Pella 86 & 95 & 19 & 3.03 & 25 & 5 & 3.32 \\
\hline \multicolumn{7}{|l|}{ Other accessions } \\
\hline Mandarin & 35 & 17 & $\mathrm{na}^{\mathrm{d}}$ & 8 & 17 & na \\
\hline LN 86-1947 & 22 & 16 & na & 7 & 13 & na \\
\hline PI 391589 & 45 & 23 & na & 5 & 2 & na \\
\hline PI 437934A & 36 & 20 & na & 6 & 6 & na \\
\hline PI 561353 & 28 & 23 & na & 5 & 21 & na \\
\hline PI 567157A & 6 & 2 & na & 11 & 8 & na \\
\hline$P$ value & $<0.01$ & $<0.01$ & $<0.01$ & $<0.01$ & $<0.01$ & $<0.01$ \\
\hline $\operatorname{LSD}(P=0.05)^{\mathrm{e}}$ & 6 & 4 & 0.79 & 6 & 4 & 0.64 \\
\hline
\end{tabular}

a Foliar ratings are the mean of three plants 8 weeks after inoculation.

${ }^{\mathrm{b}}$ Stem ratings are the mean of three stems 8 weeks after inoculation.

${ }^{\mathrm{c}} \log _{10}$ of the quantity of DNA of Phialophora gregata from plant stems detected with a quantitative PCR assay.

d Samples not assayed.

${ }^{\mathrm{e}}$ LSD Fisher's least significant difference. 
2002 and 2003 with a range from $\log _{10} 4.3$ to $4.7 \mathrm{CFU}$ per gram of stem tissue (Table 2). Pella 86 expressed greater than $85 \%$ foliar and stem symptom severity and had the lowest population density of all susceptible accessions from 2002 to 2004. PI 437833, LN94-14862, and Bell expressed less than $10 \%$ foliar symptom severity, but each had population densities that were not significantly different from those of Century 84 and Corsoy 79 in 2002 and 2003 (Table 2). Pella 86 had a significantly lower population density than the three aforementioned resistant accessions in 2002 (Table 2). Comparing all the resistant accessions evaluated, L84-5873 had the lowest pathogen population density. L845873 had a lower population density, although not statistically significant, than Bell and PI 437833 in 2003, and a statistically significant lower population density compared to all other accessions evaluated in 2004 (Table 2).

Quantities of DNA of P. gregata in soybean stems differed significantly among some soybean accessions in 2002, 2003, and 2004 (Table 2). The susceptible culti- vars Corsoy 79 and Century 84 had the highest quantity of pathogen DNA in stem tissue in 2003 and 2004, with a range from $\log _{10} 5.0$ to 6.9 copies (Table 2). Pella 86 had the lowest DNA copy number of all susceptible cultivars in 2003 and 2004, and also had a lower copy number than many resistant accessions (Table 2). Most of the resistant accessions had low symptom severity, but a DNA copy number that was similar to susceptible accessions (Table 2). An exception in 2003 and 2004 was Dwight, with less than $10 \%$ foliar and stem symptom severity, and a DNA copy number statistically lower than Corsoy 79 and Century 84. The accession L84-5873 also had low foliar and stem severity and lower DNA copy number than Century 84 in 2003 and 2004 (Table 2).

Evaluation of accessions for resistance to genotypes $A$ and $B$ in controlled environments. Accessions differed in foliar and stem symptom severity when inoculated with genotypes A or B. Bell, Dwight, IA2008R, Savoy, L845873, and PI 567157A developed less than $6 \%$ foliar and stem symptom severity after inoculation with genotype A (Table 3). Other accessions developed high symptom severity after inoculation with genotype A, but low symptoms when inoculated with genotype B. For example, PI 437934A, PI 391589, and PI 567157A had less than $8 \%$ internal stem severity after inoculation with genotype $\mathrm{B}$, and were not significantly different when compared to Bell. Pella 86 expressed more severe symptoms than other soybean accessions inoculated with genotype B (Table 3).

Differences in pathogen colonization were detected using qPCR in plants grown in controlled environments. Two susceptible cultivars, Corsoy 79 and Century 84, had the highest pathogen DNA quantity ranging from $\log _{10} 6.19$ to 6.65 copies for both genotypes (Table 3 ). The susceptible cultivar Pella 86 had a quantity of $\log _{10}$ 3.03 and 3.32 when inoculated with genotype A and B, respectively, which was the lowest DNA quantity of all susceptible accessions, and not statistically different when compared to many of the resistant accessions (Table 3). The resistant cultivar Bell had significantly lower DNA quanti-
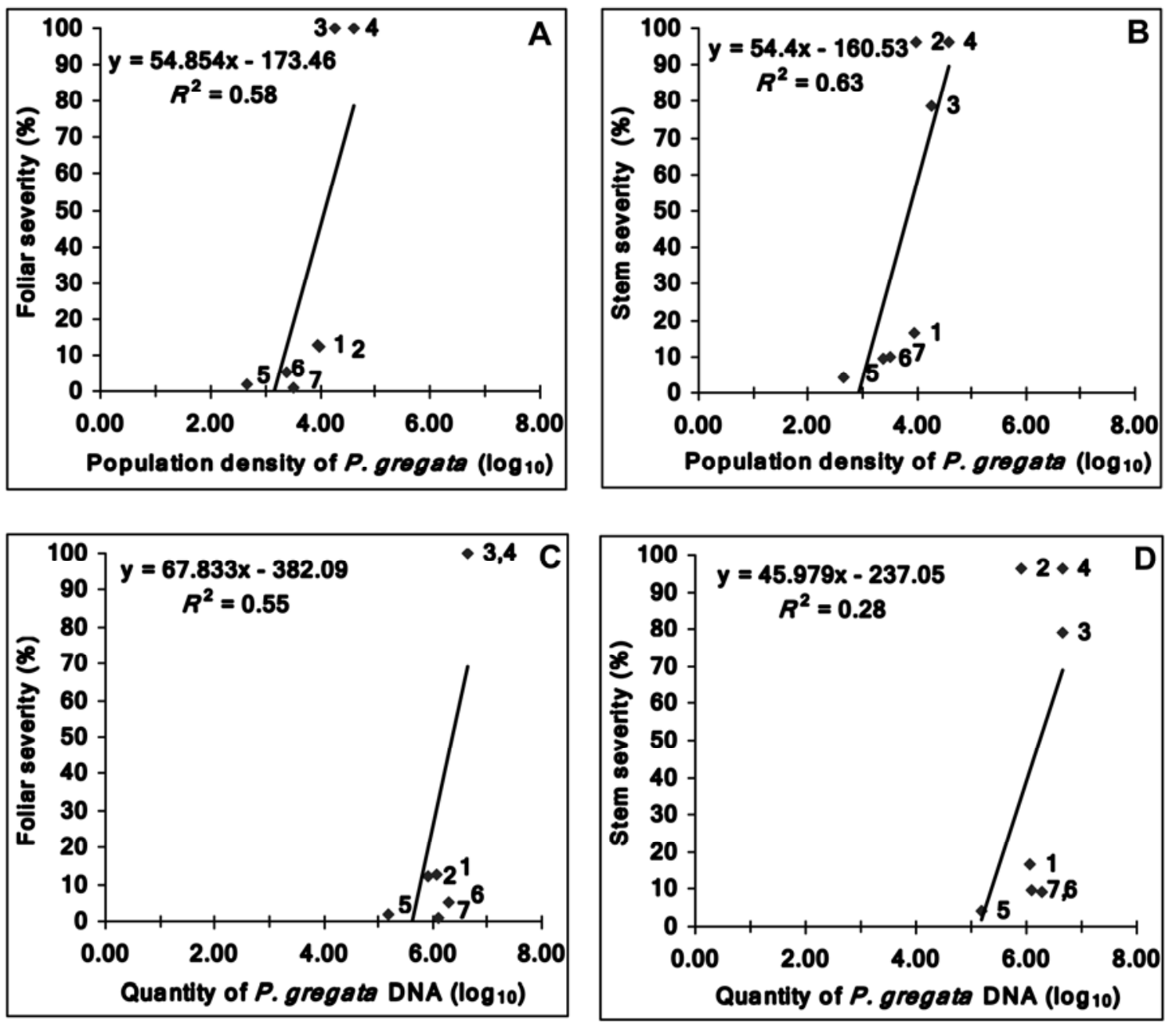

Fig. 1. Relationship between population density $\left(\mathrm{CFU} \mathrm{g} \mathrm{g}^{-1}\right)(\mathbf{A}$ and $\mathbf{B})$ or quantity of DNA (C and D) of Phialophora gregata in stem tissue and symptom severity in 2003 in the field. Data from 2002 and 2004 not shown. Seven soybean accessions were evaluated for foliar symptom severity and stem symptom severity at the R7 (beginning maturity) growth stage. Accessions are labeled: 1 - Bell; 2 - BSR101; 3 - Century 84; 4 - Corsoy 79; 5 - Dwight; 6 IA2008R; 7 - LN84-5873. 
ties ranging from $\log _{10} 2.30$ to 2.33 copies for genotypes A and B (Table 3). Other resistant accessions L84-5873 and Dwight had the lowest quantity of DNA detected in stem tissue when inoculated with genotype A (Table 3). BSR101 and L84-5873 had the lowest quantity of DNA when inoculated with genotype B.

Some accessions with low symptom severity had DNA copy numbers not significantly different from accessions with high symptom severity. PI 437883 and IA2008R expressed resistance to symptom development caused by both genotypes, but were susceptible to colonization by both genotypes as measured by high DNA quantities (Table 3). Symptom severity of IA2008R after inoculation with each genotype was similar and ranged from 1 to $2 \%$; however, the DNA quantity of each genotype differed (Table 3). Foliar and stem symptom severities of LN807579 were 6 and $4 \%$, respectively, and had a low quantity of pathogen DNA similar to Bell when inoculated with genotype B (Table 3). In contrast, foliar and stem symptom severities for LN80-7579 when inoculated with genotype A were 22 and
$24 \%$, respectively, and had a $\log _{10}$ quantity of pathogen DNA of 3.74 that was significantly higher than Bell.

Relationship between the quantity of DNA of $P$. gregata, CFU, and symptom severity. Seven accessions evaluated in field experiments were used to evaluate correlations between the quantity of DNA of $P$. gregata, $\mathrm{CFU} / \mathrm{g}$ stem tissue, and symptom severity at R7. Figures show correlations for 2003, but correlations for 2002 and 2004 were similar and are not shown. Foliar symptom severity was positively correlated with CFU in $2002\left(r^{2}=\right.$ $0.47), 2003\left(r^{2}=0.58\right)$, and $2004\left(r^{2}=\right.$ 0.42 ) (Fig. 1). Stem symptom severity was positively correlated with CFU in $2002\left(r^{2}\right.$ $=0.42), 2003\left(r^{2}=0.63\right)$, and $2004\left(r^{2}=\right.$ 0.49) (Fig. 1). Spearman rank correlations of foliar and stem symptom severity and the CFU of $P$. gregata were also positive and significant $\left(r_{s}=0.55, \mathrm{p}|\rho|<0.0001 ; r_{s}\right.$ $=0.43, \mathrm{p}|\rho|=0.0079)$. Foliar symptom severity was also positively correlated with the pathogen DNA content in stem tissue in $2002\left(r^{2}=0.24\right), 2003\left(r^{2}=0.55\right)$, and $2004\left(r^{2}=0.49\right)$ (Fig. 1). Stem symptom severity at the R7 growth stage was posi- tively correlated with the quantity of DNA in stem tissue in $2002\left(r^{2}=0.22\right), 2003\left(r^{2}\right.$ $=0.28)$, and $2004\left(r^{2}=0.62\right)$ (Fig. 1). Spearman rank correlations of foliar and stem symptom severity and the quantity of pathogen DNA were also positive and significant $\left(r_{s}=0.52, \mathrm{p}|\rho|<0.0001 ; r_{s}=\right.$ $0.30, \mathrm{p}|\rho|=0.0079)$.

The relationship between foliar and stem symptom severity and DNA quantity was greater in controlled environments than in field conditions (Fig. 2). Foliar disease severity had better correlation with DNA quantity of genotypes A and B than stem disease severity. Plants infected with genotype A had a correlation of 0.79 between foliar severity and DNA quantity, while the correlation between stem severity and DNA quantity was 0.55 (Fig. 2). Plants infected with genotype B had a correlation of 0.75 between foliar severity and DNA quantity, and the correlation between stem severity and DNA quantity was 0.45 (Fig. 2).

\section{DISCUSSION}

Soybean accessions were evaluated for resistance to BSR symptom development
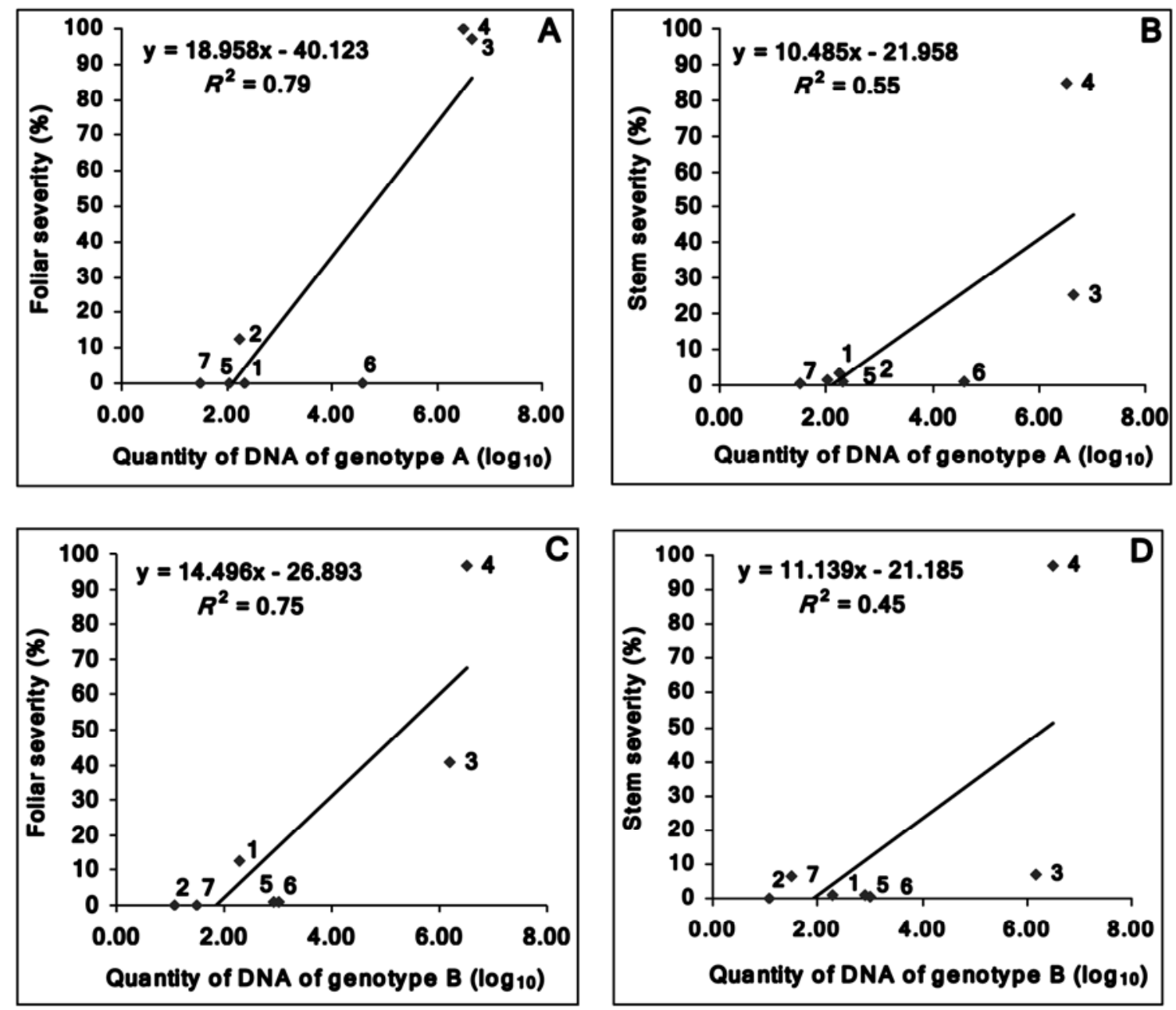

Fig. 2. Relationship between the quantity of DNA of genotype A (A and B) and genotype B (C and D) of Phialophora gregata in stem tissue and symptom severity in 2003 in controlled environments. Seven soybean accessions were evaluated for foliar symptom severity and stem symptom severity 8 weeks after inoculation. Accessions are labeled: 1 - Bell; 2 - BSR101; 3 - Century 84; 4 - Corsoy 79; 5 - Dwight; 6 - IA2008R; 7 - LN84-5873. 
and to colonization by $P$. gregata in field and controlled environments by determining the symptom severity, pathogen population density in stems, and pathogen DNA content in stems. This is the first report of the utilization of both pathogen population and DNA quantity to characterize soybean accessions for reaction to genotypes A and B of $P$. gregata.

Evaluation of resistance based on symptom severity was accomplished in controlled and field environments, but differences in colonization by $P$. gregata were more consistent in the greenhouse based on DNA quantities. In the field, there were significant differences among accessions for quantity of pathogen DNA, but the range of quantities was small. Results from the field also indicate that the quantity of pathogen DNA and population density of $P$. gregata in stems of the resistant cultivars Bell and PI 437833, and the susceptible cultivar Corsoy 79, were not different. The differences between these cultivars in the field were only detected using symptom severity ratings, but differences in both symptom severity and DNA quantity were detected in controlled environments where the susceptible cultivars had significantly greater pathogen DNA than resistant cultivars Bell and PI 437833.

Resistant and susceptible accessions may have been more readily distinguished in the greenhouse than in the field based on the population density and quantity of pathogen DNA due to timing of sample collection. Collection of stems from the field during the R7 growth stage was used to assess the population density of $P$. gregata, and to standardize sampling across a range of maturity groups. As plants senesce, $P$. gregata transitions from a pathogen to a saprophyte and may reproduce independently of resistance as the plant resources are focused on pod-fill. Plants in the greenhouse were assayed for differences in the quantity of DNA of $P$. gregata 8 weeks after inoculation when plants were at early reproductive growth stages. Sampling prior to the R7 growth stage in the field may improve our ability to distinguish resistant and susceptible accessions based on pathogen colonization. Differences in pathogen DNA quantity were more detectable at growth stages before R7 in controlled environments.

Results indicate that some accessions may be resistant to both pathogen colonization and symptom severity, while others may only be resistant to either symptom expression or pathogen colonization. PI 437833 carries the Rbs 2 source of resistance, and is resistant to symptom development. In controlled environments, the pathogen DNA quantity detected in stem tissue of this accession was significantly greater than that of Bell. A similar trend was observed with the resistant cultivar IA2008R when inoculated with genotype A. IA2008R is susceptible to colonization by genotype A, but resistant to colonization by genotype $\mathrm{B}$ in controlled environments. L84-5873 had the lowest population density and DNA quantity of all accessions compared in field and controlled environments, and developed minimal foliar and stem symptoms. This result indicates that L84-5873 is resistant to colonization by both genotypes of $P$. gregata and to symptom development (16). In contrast, Pella 86, a susceptible cultivar, expressed high foliar and stem symptom severity, but had a low pathogen population density in the field and a low DNA quantity in controlled environments. Pella 86 may be resistant to pathogen colonization, but possibly susceptible to the phytotoxin that is implicated as the cause of foliar symptoms (5).

Other potential new sources of resistance to genotypes A and B were identified based on symptom severity, but not on pathogen colonization. PI 437934A, PI 391589, and PI 567157A all expressed mild symptom severity in the greenhouse and field. Inoculation with genotype B resulted in low internal symptom severity for PI 437934A, PI 391589, and PI 567157A, and therefore, they may be important sources of resistance to symptom development. PI 567157A expressed low foliar and internal stem severity when inoculated with genotype A. The population density of $P$. gregata in stem tissue of these accessions was determined in the field only in 2002, but future studies should determine the DNA quantity and population density.

Symptom severity was positively correlated with the population density and quantity of DNA of $P$. gregata in stem tissue. Greater foliar symptom severity usually predicted a higher population of $P$. gregata in stem tissue. Similar results are also reported for a positive correlation between disease severity and pathogen DNA (7). In controlled environments, foliar symptom severity was strongly correlated with the population of pathogen DNA at plant reproductive growth stages. In general, results suggested foliar symptom severity predicted the population density and DNA quantity of $P$. gregata better than stem symptom severity. CFU were not determined in greenhouse or growth chamber experiments because previous research has indicated the population density is difficult to assay in controlled environments (C. Grau, unpublished data). Evaluating accessions in the greenhouse using qPCR at earlier growth stages may be a rapid method to identify resistant and susceptible accessions and ought to be investigated.

This is the first report of a comparison of the population density and quantity of DNA of $P$. gregata in prematurity soybean stems of resistant and susceptible soybean accessions. Results from this research indicate resistant accessions, based on symptom severity, can vary in degrees of colonization by $P$. gregata. Breeding programs should consider using germplasm that not only expresses low symptom severity, but also restricts colonization of host tissue. Research is needed to determine if low colonization by $P$. gregata translates to greater protection of yield and a decline in inoculum of $P$. gregata in fields after successive years of planting.

\section{ACKNOWLEDGMENTS}

We thank Nancy Koval and Tristan Mueller for assistance with field work and Marcus Vinje for helping with DNA extractions and PCR. This study was funded by the College of Agriculture and Life Sciences, University of Wisconsin-Madison, the Wisconsin Soybean Marketing Board, and the North Central Soybean Research Program.

\section{LITERATURE CITED}

1. Allington, W. B., and Chamberlain, D. W. 1948. Brown stem rot of soybean. Phytopathology 38:793-802.

2. Chen, S. Y., Porter, P. M., Orf, J. H., Reese, C. D., Stienstra, W. C., Young, N. D., Walgenbach, D. D., Schaus, P. J., Arlt, T. J., and Breitenbach, F. R. 2001. Soybean cyst nematode population development and associated soybean yields of resistant and susceptible cultivars in Minnesota. Plant Dis. 85:760-766.

3. Grau, C. R., Dorrance, A. E., Bond, J., and Russin, R. S. 2004. Fungal diseases. Pages 679763 in: Soybeans: Improvement, Production, and Uses. H. R. Boerma and J. E. Specht, eds. American Society of Agronomy, Madison, WI.

4. Gray, L. E. 1971. Variation in pathogenicity of Cephalosporium gregatum isolates. Phytopathology 61:1410-1411.

5. Gray, L. E., and Chamberlain, D. W. 1975 Evidence for toxin production by a strain of Cephalosporium gregatum. Phytopathology 65:89-90.

6. Harrington, T. C., and McNew, D. L. 2003. Phylogenetic analysis places the Phialophora like anamorph genus Cadophora in the Helotiales. Mycotaxon 87:141-151.

7. Hogg, A. C., Johnston, R. H., and Dyer, A. T. 2007. Applying real-time quantitative PCR to Fusarium crown rot of wheat. Plant Dis. 91:1021-1028.

8. Horsfall, J. G., and Barratt, R. W. 1945. An improved grading system for measuring plant disease. Phytopathology 35:655.

9. Hughes, T. J., Chen, W., and Grau, C. R. 2002. Pathogenic characterization of genotypes A and $\mathrm{B}$ of Phialophora gregata f. sp. sojae. Plant Dis. 86:729-735.

10. Hughes, T. J., Kurtzweil, N. C., Diers, B. W., and Grau, C. R. 2004. Resistance to brown stem rot in soybean germ plasm with resistance to the soybean cyst nematode. Plant Dis. 88:761-768.

11. Larsen, R. C., Vandemark, G. J., Hughes, T. J., and Grau, C. R. 2007. Development of a realtime polymerase chain reaction assay for quantifying Verticillium albo-atrum DNA in resistant and susceptible alfalfa. Phytopathology 97:1519-1525.

12. Malvick, D. K., and Grunden, E. 2005. Isolation of fungal DNA from plant tissue and removal of DNA amplification inhibitors. Mol. Ecol. Notes 5:958-960.

13. Malvick, D. K., and Impullitti, A. E. 2007. Detection and quantification of Phialophora gregata in soybean stem and soil samples with a quantitative, real-time PCR assay. Plant Dis. 91:736-742.

14. Mengistu, A., Tachibana, H., and Grau, C. R 1991. Selective medium for isolation and enumeration of Phialophora gregata from soybean straw and soil. Plant Dis. 75:196-199. 
15. Nelson, R. L., Nickell, C. D., Orf, J. H., Tachibana, H., Gritton, E. T., Grau, C. R., and Kennedy, B. W. 1989. Evaluating soybean germ plasm for brown stem rot resistance. Plant Dis. 73:110-114.

16. Nickell, C. D., and Bernard, R. L. 1992. Registration of L84-5873 and L84-5932 soybean germplasm lines resistant to brown stem rot. Crop Sci. 32:835

17. Pearson, C., Schwenk, F. W., Crowe, F. J., and Kelley, K. 1984. Colonization of soybean roots by Macrophomina phaeseolina. Plant Dis. 68:1086-1088.

18. Phillips, D. V. 1971. Influence of air temperature on brown stem rot of soybean. Phytopathology 61:1205-1208.

19. Ritchie, S. W., Hanway, J. J., Thompson, H. E., and Benson, G. O. 1997. How a soybean plant develops. Iowa State University of Science and Technology Coop. Ext. Serv. No. 35.

20. Schneider, R. W., Sinclair, J. B., and Gray, L. E. 1972. Etiology of Cephalosporium gregatum in soybean. Phytopathology 62:345-349.

21. Short, G. E., and Wyllie, T. D. 1978. Inoculum potential of Macrophomina phaeseolina. Phytopathology 68:742.

22. Sills, G. R., Gritton, E. T., and Grau, C. R. 1991. Differential reactions of soybean genotypes to isolates of Phialophora gregata. Plant Dis. 75:687-690.

23. Silvar, C., Diaz, J., and Merino, F. 2005. Realtime polymerase chain reaction quantification of Phytophthora capsici in different pepper genotypes. Phytopathology 95:1423-1429.

24. Smith, G. S., and Carvil, O. N. 1997. Field screening of commercial and experimental soybean cultivars for their reaction to Macrophomina phaseolina. Plant Dis. 81:363-368.

25. Tabor, G. M., Tylka, G. L., and Bronson, C. R. 2007. Genotypes A and B of Cadophora gre gata differ in ability to colonize susceptible soybean. Plant Dis. 91:574-580.

26. Tabor, G. M., Tylka, G. L., Cianzio, S. C., and Bronson, C. R. 2003. Resistance to Phialophora gregata is expressed in the stems of resistant soybeans. Plant Dis. 87:970-976.

27. U.S. Dep. Agric. National Plant Germplasm System: Germplasm Resources Information Network (GRIN) http://www.ars-grin.gov/npgs/, 2008 [cited].

28. Wrather, J. A., and Koenning, S. R. 2006 Estimates of disease effects on soybean yields in the United States 2003 to 2005. J. Nematol. 38:173-180. 